\title{
IMPLEMENTASI BIMBINGAN DAN KONSELING DARING PADA MADRASAH TSANAWIYAH DI JAWA TIMUR
}

\author{
Agus Akhmadi ${ }^{1}$, Ninik Supriyati ${ }^{2}$ \\ ${ }^{1}$ Balai Pendidikan dan Pelatihan Keagamaan Surabaya \\ ${ }^{2}$ Balai Pendidikan dan Pelatihan Keagamaan Surabaya \\ 1agusakhmadi63@gmail.com
}

https://doi.org/10.36052/andragogi.v9i2.242

Diterima: 11 Oktober 2021 | Disetujui: 22 November 2021 | Dipublikasikan: 31 Desember 2021

\begin{abstract}
Abstrak
Layanan bimbingan dan konseling daring merupakan pendekatan layanan jarak jauh dimasa pandemi COVID-19. Penelitian ini bertujuan untuk mendeskripsikan proses dan hasil layanan bimbingan dan konseling daring madrasah Tsanawiyah dimasa pandemi COVID-19. Metode penelitian menggunakan survei dengan pendekatan deskriptif. Responden penelitian sejumlah 383 siswa penerima layanan bimbingan dan konseling daring Madrasah Tsanawiyah di Jawa Timur. Pengumpulan data dilakukan dengan angket. Instrumen penelitian diunggah dalam google formulir yang dikirimkan melalui guru bimbingan dan konseling. Data diolah dengan statistik deskriptif dan dianalisa secara deduktif kualitatif. Hasil penelitian ini menunjukkan bahwa layanan bimbingan dan konseling daring terlaksana dengan baik. Proses layanan daring menyenangkan dan mudah untuk peserta didik, efektifitas layanan baik. Terdapat hambatan pada sarana prasarana layanan daring pada sebagian peserta didik.
\end{abstract}

Kata Kunci: Bimbingan dan konseling, covid-19, layanan daring.

\begin{abstract}
Online guidance and counseling service is a service that is used during the pandemic. This study aims to describe the process and results of online counseling services in madrasas. The research method used is a survey with a descriptive approach. Research respondents were 383 students who received online guidance and counseling services at Madrasah Tsanawiyah. Questionnaires and interviews were used to collect the data. The instrument is uploaded in a google form, sent to the students through the guidance and counseling teachers. The questionnaire data were processed by descriptive statistics and analyzed through descriptive qualitative techniques. The results of this study indicate that online guidance and counseling services are carried out well. The online service process is fun and easy for students, the service is effective. There was an obstacle for several students due to the internet problem.
\end{abstract}

Keywords: Guidance and counseling, covid-19, online service. 


\section{PENDAHULUAN}

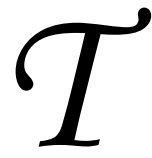

elah terjadi perubahan dalam layanan guru bimbingan dan konseling (BK) selama pandemi COVID-19 di madrasah/sekolah. Layanan yang sebelumnya dilakukan dengan tatap muka harus berubah, karena adanya aturan "social distances". Dengan adanya layanan yang baru tersebut, banyak peserta didik yang kesulitan dalam menerima layanan (Putra \& Shofaria, 2020). Kesulitan dalam layanan bimbingan dan konseling tidak hanya menyangkut masalah sarana prasarana tetapi juga menyangkut masalah kebiasaan layanan bimbingan dan konseling yang berubah dari layanan langsung berbasis tatap muka menjadi berbasis online/daring (Gozali, 2020). Sebagaimana layanan pembelajaran, ada peserta didik yang kurang mampu menjalani proses pendidikan secara daring. (Rachmat \& Krisnadi, 2020) bahwa belajar secara daring kurang efektif dan berbanding lurus dengan kurang pahamnya peserta didik pada pembelajaran. Kendala yang dialami peserta didik adalah kendala dari kuota data yang terbatas dan jaringan internet yang lambat. Survei yang dilakukan oleh UI menemukan bahwa hanya 48 persen peserta didik sekolah menengah di Indonesia yang mampu terlibat secara aktif dalam proses belajar (Mirzalin, 2020). Tilaar (2021) menunjukkan bahwa layanan daring telah membawa berbagai akibat pada peserta didik dan orang tua dalam memenuhi kebutuhan selama pandemi.

Studi terdahulu tentang kesulitan layanan selama pandemik lebih melihat kesulitan dari dua perspektif. Pertama, studi tentang kesulitan terfokus pada ketersediaan perangkat teknologi dan akses terhadap internet (Faize \& Nawaz, 2020; Kimkong Heng \& Koemhong Sol, 2020; Mukhtar et al., 2020; Wahyu \& Simanullang, 2020). Kedua, studi yang melihat kesulitan pada tataran keluarga dimana peserta dari keluarga miskin mengalami kendala di dalam menjalankan proses daring (Arifiati et al., 2020; Fatoni et al., 2020; Fini et al., 2020; Monteleoni, 2006). Fatoni et al (2020) mengatakan "the advantage that students feel with online learning is that they can listen at home, they are not limited by the place, they can listen anytime anywhere, and they are not limited by time or space grouped into comfortable educational themes".

Studi tentang layanan bimbingan dan konseling yang efektif selama masa pandemi COVID-19 adalah layanan menggunakan media aplikasi whatsapp, google classroom dan sebagainya. Beberapa inovasi layanan bimbingan dan konseling berbasis daring berupa bimbingan dan konseling melalui zoom, google meet, webex meet, sinema konseling dan cyber counseling berbasis email, cyber counseling berbasis chat asynchronous, cyber counseling berbasis teks dan cyber counseling berbasis facebook (Rokhyani, 2021). Sebagaimana penelitian (Febriani \& M Fauzi, 2021) bahwa terdapat pembaharuan pelaksanaan layanan bimbingan dan konseling selama pandemi COVID-19, dan terdapat metode layanan bimbingan dan konseling yang memperluas kesempatan siswa mendapatkan layanan. Dalam layanan masa pandemi ini, $(H$. Purwaningsih, 2021) menegaskan bahwa peran guru bimbingan dan konseling sangat urgen karena merupakan bagian integral pendidikan yang ikut menangani berbagai masalah benturan antara guru dengan peserta didik yang mengalami masalah belajar, kekurangnyamanan dan hambatan dalam belajar.

Studi ini berupa layanan pendidikan didalamnya terdapat pembelajaran serta layanan bimbingan dan konseling yang memiliki beberapa kesamaan layanannya di masa pandemi. Dua kecenderungan di atas memperlihatkan bahwa tulisan yang ada berorientasi pada ukuran-ukuran objektif dan parsial. Bagaimana kesulitan itu dievaluasi pada setiap kelompok masyarakat yang tidak 
mendapatkan perhatian pada studi yang ada. Pada saat yang sama studi tersebut melihat terbatas pada aspek tertentu sehingga tidak diperoleh pemahaman yang komprehensif.

Tujuan tulisan ini melengkapi kekurangan dari studi yang ada yang cenderung bersifat parsial. Tulisan ini secara khusus bertujuan selain memetakan layanan BK yang berubah, hambatan dan kesulitan yang terjadi dalam layanan BK, juga menganalisis faktorfaktor/kondisi-kondisi yang menyebabkan terjadinya kesulitan layanan BK daring di masa pandemi. Jawaban atas dua pertanyaan (masalah) memungkinkan studi ini memberikan pemahaman tentang transformasi dalam dunia layanan BK yang terjadi selama pandemic covid-19.

Kesulitan layanan BK daring pada masa pandemic bukan semata-mata menyangkut persoalan teknologi tetapi juga menyangkut transformasi dunia layanan itu sendiri. Layanan daring mengubah tradisi layanan dari berpusat pada guru BK (konselor) ke tradisi layanan yang berpusat pada teknologi. Penggunaan teknologi dalam layanan BK telah mengurangi/ menghilangkan ketergantungan peserta didik pada guru BK dalam proses bimbingan di madrasah baik pada pemahaman, sikap dan kemandirian. Pada saat yang sama guru BK/ konselor kehilangan peran tradisionalnya dalam layanan bimbingan dan konseling. Dengan demikian layanan daring selama pandemic merupakan suatu tanda dari perubahan tradisi layanan dari layanan BK konvensional yang bersifat face to face menuju layanan yang terbuka dan mandiri.

Wabah COVID-19 telah melanda negaranegara di dunia dan memberikan tantangan tersendiri bagi layanan pendidikan (Satuan Tugas Penanganan COVID-19, 2021). Tantangan terhadap pendidikan termasuk layanan bimbingan dan konseling berupa larangan pembelajaran tatap muka (konvensional), hal itu terjadi karena adanya larangan berkerumun, pembatasan sosial (social distancing) dan menjaga jarak (physical distancing), memakai masker dan selalu mencuci tangan. Perintah untuk menyelenggarakan layanan secara daring disampaikan pemerintah lewat berbagai aturan agar pembelajaran dilaksanakan namun tanpa tatap muka (Sadikin \& Hamidah, 2020).

Pandemi COVID-19 telah menyebar ke berbagai penjuru dan memberikan dampak terhadap lingkungan pendidikan dan layanan berupa instruksi tentang pencegahan penyebaran corona virus diesease (Covid-19) dengan menerapkan pembelajaran daring. WHO memberikan himbauan untuk menghentikan acara-acara yang dapat menyebabkan masa berkerumun, sehingga layanan tatap muka yang mengumpulkan banyak peserta dihentikan karena sangat berpotensi menyebarkan Covid-19. Layanan pendidikan diselenggarakan dengan skenario yang mampu mencegah interaksi secara fisik antara peserta didik dengan peserta lainnya dan antara peserta dengan guru, yaitu dengan penggunaan teknologi digital yang memungkinkan peserta didik dan guru dapat melaksanakan proses layanan pendidikan walaupun mereka ditempat yang berbeda (Firman \& Rahayu, 2020). Penanganan layanan pendidikan dengan daring memiliki kekuatan, tantangan dan hambatan tersendiri (Jamaluddin et al., 2020).

Layanan bimbingan dan konseling mengalami perubahan karena pandemi Covid-19. Layanan berbasis teknologi informasi dan komunikasi (TIK) yang dilaksanakan saat ini merupakan layanan yang menggunakan teknologi untuk meningkatkan efektifitas layanan bimbingan dan konseling, mulai dari persiapan, perencanaan, pelaksanaan, evaluasi dan tindak lanjut. Dalam hal pemanfaatan TIK dengan jaringan internet saat ini menjadi kecenderungan masyarakat karena hampir semua bidang kehidupan menggunakan layanan berbasis TIK. Jumlah pengguna 
internet pada 2020 sebanyak 175,4 juta pengguna, pengguna internet mobile seperti smartphone/tablet mencapai 338,2 juta pengguna dari 272,1 juta jiwa (Gozali, 2020).

Layanan BK berbasis TIK saat ini juga semakin tidak terelakkan di era digital, yang menawarkan kemudahan dan keuntungan seperti lebih fleksibel tanpa terikat ruang dan waktu, mempermudah peserta didik mengakses layanan, memperkaya materi bimbingan, mengaktifkan proses layanan, terbukanya proses layanan bimbingan dan konseling, meningkatkan efisiensi layanan, serta mendukung belajar mandiri (Kamalia et al., 2020). Proses layanan bimbingan dan konseling daring terdapat kelemahan, yaitu dalam interaksi personal, namun memiliki manfaat dalam memperluas layanan BK, untuk itu kelengkapan piranti Teknologi Informasi dan Komunikasi (TIK), dan kemampuan guru BK menerapkan sistem layanan daring semakin diperlukan. Oleh karena itu implementasi layanan BK daring penting dikaji, bagaimana proses penerapannya, bagaimana tingkat keberhasilannya, apa kendala dan tantangan dan solusi apa yang diperlukan.

Pandemi covid-19 mempengaruhi aktifitas pendidikan (Almarzooq et al., 2020) termasuk di dalamnya layanan BK. Layanan BK semakin dituntut kreatif dan inovatif dengan berbagai jenis layanan yang memanfaatkan kecanggihan teknologi informasi dan komunikasi, baik jenis dan pola layanannya. Fasilitas untuk layanan BK daring yang dibutuhkan adalah komputer/ HP, jaringan, koneksi internet dan media elektronik lainnya yang mendukung layanan BK. Pemanfaatan internet dalam layanan bimbingan dan konseling, (Gozali, 2020) sebagaimana tabel 1.

Layanan bimbingan dan konseling daring merupakan pola baru dalam bimbingan dan konseling di madrasah. Dalam layanan klasikal, bimbingan dilaksanakan melalui aplikasi seperti google classroom. Guru BK
Tabel 1 Penggunaan TIK layanan BK online

\begin{tabular}{|c|c|c|}
\hline Sifat & Layanan & Piranti TIK \\
\hline Individual & $\begin{array}{l}\text { Konseling } \\
\text { Konsultasi } \\
\text { Homevisit }\end{array}$ & $\begin{array}{l}\text { Telepon, Vidoe Call, WA, Line, } \\
\text { Telegram, Skype, Facebook } \\
\text { Massenger. }\end{array}$ \\
\hline Kelompok & $\begin{array}{l}\text { Konseling } \\
\text { Bimbingan } \\
\text { Konferensi } \\
\text { kasus } \\
\text { Kolaborasi } \\
\text { Alih tangan } \\
\text { kasus } \\
\text { Mediasi } \\
\text { Advokasi }\end{array}$ & $\begin{array}{l}\text { - Google class, schoology, seesaw } \\
\text { class. } \\
\text { - WA versi } 2.20 .189 \text { panggilan } \\
\text { dan Vidoe Call maksimal } 8 \\
\text { orang. Grup perpesanan } \\
\text { menampung } 256 \text { anggota. } \\
\text { - Telegram versi 6.2.0. Grup } \\
\text { perpesanan mampu } \\
\text { menampung } 200.000 \text { anggota. } \\
\text { - Youtube live streaming, } \\
\text { Facebook live streaming, Zoom, } \\
\text { Google Meet, Webex Meeting, } \\
\text { Jitsi dan perangkat aplikasi lain } \\
\text { dari berbagai platform. }\end{array}$ \\
\hline Klasikal & $\begin{array}{l}\text { Layanan } \\
\text { Orientasi } \\
\text { Layanan } \\
\text { Informasi } \\
\text { Antar kelas } \\
\text { Kelas besar }\end{array}$ & $\begin{array}{l}\text { - Google class, schoology, } \\
\text { seesaw class. } \\
\text { - Telegram versi 6.2.0. Grup } \\
\text { perpesanan mampu } \\
\text { menampung } 200.000 \text { anggota } \\
\text { - Youtube live streaming, } \\
\text { Facebook live streaming, Zoom, } \\
\text { Google Meet, Webex Meeting, } \\
\text { Jitsi dan perangkat aplikasi lain } \\
\text { dari berbagai platform. }\end{array}$ \\
\hline
\end{tabular}

memberikan layanan informasi materi bimbingan dalam sesi layanan klasikal secara daring. Sebagai model layanan baru dan berbeda dengan layanan tatap muka sebelumnya, guru BK mengungkapkan beberapa kendala dan kesulitan baik softskill maupun hardskill. (Kamalia et al., 2020) menyebutkan kendala dalam layanan BK daring. Pertama: aplikasi google classroom yang kurang tertangkap oleh pengguna, interaksi yang kurang optimal, interaksi terbatas, motivasi peserta yang cenderung menurun. Kedua, memiliki perangkat tetapi masih jadul yang kurang support dengan kebutuhan e-learning. Ketiga, kurang tersedianya kuota yang memadai untuk berinteraksi secara normal dalam daring. Keempat, jaringan internet bermasalah sehingga harus mencari jaringan. Kelima, aliran listrik yang sering putus. Kendala ini menjadi penghambat serius dalam layanan bimbingan dan konseling daring. Dengan demikian layanan bimbingan dan konseling 
daring sebagai pola baru dalam pendidikan yang berbeda dengan layanan BK sebelumnya dengan pendekatan jarak jauh terdapat beberapa hambatan dan kesulitan.

Pelaksanaan layanan bimbingan dan konseling daring menghadapi beberapa hambatan dan kesulitan baik infrastruktur maupun suprastruktur. Layanan bimbingan dan konseling daring setidaknya membutuhkan ketersediaan akses internet yang mampu menyokong proses layanan, Rahman (2020) mengatakan terdapat 5 kendala dalam layanan daring, yaitu: Pertama, tidak memiliki HP atau computer untuk layanan yang kompatibel dengan kegiatan. Kedua, memiliki tetapi masih jadul yang kurang support dengan kebutuhan. Ketiga, kurang tersedianya kuota yang memadai untuk berinteraksi secara normal dalam daring. Kempat, jaringan internet bermasalah dan kelima aliran listrik yang sering putus. (Fauzi et al., 2020) juga menemukan kendala beberapa siswa tidak memiliki handphone, biaya yang kurang memadai untuk paket data, jaringan internet yang lelet sehingga siswa terganggu dalam menerima layanan. Dengan penemuan tersebut semakin nyata kendala yang dialami dalam pelaksanaan layanan di masa pandemi COVID-19 ini.

\section{METODE PENELITIAN}

Isu pokok penelitian ini adalah implementasi layanan bimbingan dan konseling daring di madrasah. Penelitian ini dilakukan terhadap apa yang terjadi pada obyek implementasi layanan BK daring madrasah ditinjau dari proses dan hasil layanan. Penelitian dilakukan terhadap pelaksanaan layanan BK daring di Madrasah Tsanawiyah Jawa Timur yang saat pandemi Covid-19 menggunakan berbagai aplikasi daring seperti e-learning, WA dan google classroom.

Obyek penelitian adalah (a) proses layanan BK yang meliputi perasaan senang pada layanan BK daring, keaktifan berpartisipasi dalam layanan BK daring, berkonsentrasi dalam mengikuti layanan BK daring dan kemudahan menemukan sumber-sumber layanan BK daring. (b) hasil layanan BK yang meliputi efektifitas layanan BK, pemahaman materi layanan, progres yang baik setelah layanan, kemandirian mengatasi masalah setelah layanan BK. Obyek penelitian ini cukup menarik dikaji karena pelaksanaan layanan BK berbasis digital merupakan hal yang masih baru, sehingga akan memberikan masukan dan perbaikan pelaksanaan layanan BK selanjutnya. Berbagai kejadian baik kendala maupun kesulitan dalam implementasi layanan BK daring di madrasah juga menjadi obyek implementasi bimbingan maupun konseling daring.

Penelitian ini termasuk penelitian survei terhadap layanan bimbingan dan konseling daring. Penelitian survei untuk mendapatkan data baik primer maupun sekunder dengan

Tabel 2 Tahapan Penelitian

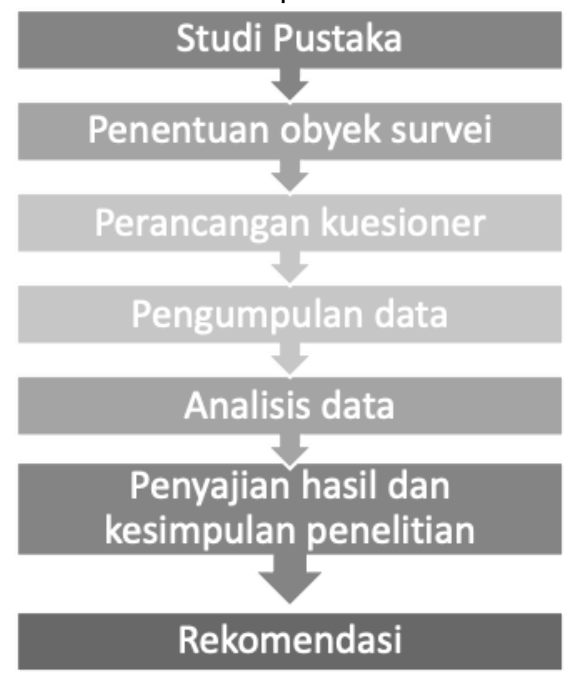

pendekatan kualitatif deskriptif terhadap implementasi layanan bimbingan dan konseling daring di era pandemi Covid-19. Data diperoleh dengan menggunakan angket dari sumber primer yaitu data yang langsung didapatkan dari para peserta didik Madrasah Tsanawiyah Jawa Timur. Data sekunder diperoleh dari guru bimbingan dan konseling. Dengan demikian pendekatan penelitian ini 
kualitatif deskriptif melalui survei untuk mendapatkan data primer dan sekunder layanan BK daring.

Penelitian ini melibatkan 383 peserta didik Madrasah Tsanawiyah yang tersebar di Jawa Timur yang diambil dengan purposive sampling dari beberapa madrasah tsanawiyah yang guru BK nya mengikuti pelatihan jarak jauh Balai Diklat Keagamaan Surabaya. Pelibatan peserta didik sebagai informan penelitian dilakukan tidak secara langsung, yaitu melalui guru BK di madrasah, dengan meminta peserta dalam kegiatan pengumpulan data melalui google form. Dengan demikian partisipan penelitian ini adalah peserta didik yang mendapatkan layanan BK di Madrasah Tsanawiyah Jawa Timur.

Penelitian ini diawali dengan studi pustaka tentang layanan BK selama pandemi Covid-19 terkait dengan strategi layanan BK, kesulitankesulitan layanan yang dialami dalam implementasinya. Tahapan penelitian adalah sebagaimana tabel 1. Kajian tentang layanan BK era pandemi Covid-19, Inovasi layanan BK yang diterapkan di madrasah dan kesulitan dalam layanan BK berbasis daring adalah fenomena menarik, dengan demikian, inovasi layanan BK daring, hambatan-kesulitan layanan dan efektifitas layanan BK daring menjadi fokus penelitian ini.

Pengumpulan data dilakukan dengan pendekatan survei dengan menggunakan angket yang dikembangkan dari komponen implementasi layanan BK. Teknik pengumpulan data dilakukan dengan cara responden dikirimi angket lewat formulir google dan diminta memilih jawaban yang tersedia di formulir google sesuai dengan apa yang dialami dalam layanan BK yang sesuai karakteristik dirinya. Untuk pengumpulan data tambahan, dilakukan melalui observasi dan wawancara terhadap beberapa guru BK madrasah untuk memperoleh informasi atas efektifitas layanan BK daring serta kesulitankesulitan dalam layanan BK sebagaimana kisi- kisi efektifitas layanan. Observasi dan wawancara karena terkendala sosial distancing dilakukan berbantuan angket dan video call.

Penelitian ini menggunakan teknik analisis deskriptif (Rimawati \& Saptomo, 2019), yaitu mentabulasi data hasil survei, kemudian dilakukan displai hasil dan mendeskripsikan

Tabel 3. Pelaksanaan Layanan BK online/daring

\begin{tabular}{|c|c|c|c|c|c|c|}
\hline No & $\begin{array}{c}\text { Unsur } \\
\text { Pelaksanaan } \\
\text { Layanan BK }\end{array}$ & $\mathrm{Ya}$ & $\%$ & Tidak & $\%$ & Tot Res \\
\hline 1. & $\begin{array}{l}\text { Perasaan } \\
\text { senang }\end{array}$ & 316 & 83 & 67 & 17 & 383 \\
\hline 2. & $\begin{array}{l}\text { Keaktifan } \\
\text { partisipasi }\end{array}$ & 354 & 92 & 29 & 8 & 383 \\
\hline 3. & $\begin{array}{l}\text { Konsentrasi } \\
\text { dalam layanan }\end{array}$ & 283 & 74 & 100 & 26 & 383 \\
\hline 4. & $\begin{array}{l}\text { Kemudahan } \\
\text { menemukan } \\
\text { sumber } \\
\text { layanan }\end{array}$ & 359 & 94 & 24 & 6 & 383 \\
\hline 5. & $\begin{array}{l}\text { Efektifitas } \\
\text { layanan }\end{array}$ & 306 & 77 & 80 & 20 & 383 \\
\hline 6. & $\begin{array}{l}\text { Pemahaman } \\
\text { terhadap } \\
\text { materi } \\
\text { layanan }\end{array}$ & 360 & 94 & 23 & 6 & 383 \\
\hline 7. & $\begin{array}{l}\text { Progres } \\
\text { perbaikan } \\
\text { setelah } \\
\text { layanan }\end{array}$ & 341 & 89 & 42 & 11 & 383 \\
\hline 8. & $\begin{array}{l}\text { Kemandirian } \\
\text { mengatasi } \\
\text { masalah }\end{array}$ & 277 & 72 & 106 & 28 & 383 \\
\hline
\end{tabular}

data. Data selanjutnya dihitung nilai rata-rata dari setiap pertanyaan, skor rata-rata pertanyaan untuk satu faktor yang sama dan skor rata-rata total. Data yang berupa hasil wawancara maupun pengamatan dianalisis kesesuaiannya dengan variabel-variabel yang di survei dan selanjutnya dilakukan interpretasi.

\section{TEMUAN DAN PEMBAHASAN}

\section{Temuan}

Pelaksanaan layanan BK di masa pandemi dijelaskan dalam tabel 3. Pelaksanaan layanan BK daring menjelaskan delapan unsur pelaksanaan layanan bimbingan dan konseling daring di madrasah. Pelaksanaan 
layanan BK di madrasah adalah sebagai berikut:

Pertama, unsur perasaan senang pada layanan BK daring, adalah sebanyak 83\% senang dan $17 \%$ tidak senang. Mereka senang terhadap layanan daring karena layanan daring sesuai dengan literasi digital atau kemampuan mereka terhadap perangkat teknologi informasi dan komunikasi. Anakanak usia SMP cenderung lebih melek (literasi) terhadap teknologi daring, sehingga mereka senang dalam layanan BK daring, mereka senang zoom dengan temantemannya, mereka menyatakan bahwa media digital yang diberikan sangat asik dan menarik, merasa senang jika diberi kesempatan untuk berkomentar lewat chatting, dan merasa tidak ada kesulitan untuk menjalankan aplikasi layanan daring. Sebagian peserta menyatakan, kesenangan layanan BK daring terkendala oleh beberapa hal seperti kesulitan kuota, sinyal terputusputus, paket internet habis. Dengan demikian layanan BK daring merupakan layanan baru yang menyenangkan dan memberi pengalaman pada peserta didik.

Kedua, unsur keaktifan berpartisipasi dalam layanan BK daring, adalah sebanyak 92\% menyatakan aktif berpartisipasi dan $8 \%$ menyatakan tidak aktif berpartisipasi. Layanan BK daring adalah sesuatu yang baru bagi peserta didik, layanan yang memberikan pengalaman baru dari model tatap muka ke digital yang saat ini menjadi minat anak-anak milineal sehingga mereka aktif berpartisipasi. Mereka yang menyatakan tidak berpartisipasi aktif karena bosan atau jenuh dengan layanan daring, sebagian mengantuk, bahkan merasa sakit dengan terlalu lama didepan HP. Dengan demikian, layanan BK daring di madrasah dapat mengkatifkan peserta didik dalam proses bimbingan dan konseling.

Ketiga, unsur konsentrasi dalam mengikuti layanan BK daring, adalah sebanyak 74\% dapat fokus konsentrasi dan 26\% tidak konsentrasi. Dalam mengikuti layanan BK daring peserta didik berlama-lama duduk didepan layar digital, sehingga ada yang sulit konsentrasi dalam layanan BK. Karena diam, mereka bosan/jenuh, mengantuk didepan HP. Kadang layanan lewat whatsapp atau $e$ learning kurang jelas tugas, pikiran menjadi kurang fokus. Kadang peserta didik merasakan tidak konsentrasi karena sinyal putus-putus dan ketinggalan penjelasan guru. Dengan demikian, konsentrasi peserta dalam layanan BK daring di madrasah menghadapi kendala.

Keempat, unsur kemudahan menemukan sumber-sumber layanan BK daring, adalah sebanyak $94 \%$ menyatakan mudah dan $6 \%$ menyatakan tidak mudah. Kemudahan layanan bimbingan dan konseling daring karena dalam layanan BK daring memungkinkan peserta mengakses berbagai informasi dari berbagai sumber dengan mudah dan cepat. Variasi sumber layanan yang disediakan dalam layanan daring memungkinkan peserta didik dapat memilih, kemudahan layanan ini dipengaruhi kemampuan peserta memanfaatkan perangkat HP, kemampuan literasi digital untuk menemukan informasi, menggunakan informasi sebagai input pemikiran, untuk memahami, untuk menganalisis, memberikan penilaian terhadap berbagai informasi. Peserta menyatakan mampu menggunakan aplikasi HP/komputer untuk layanan BK yang berbentuk format teks, gambar, audio dan video, mampu memanfaatkan google classroom, zoom meeting, whatsapp, elearning, sehingga mempermudah proses layanan BK daring.

Kelima, unsur efektifitas layanan BK daring, adalah sebanyak $80 \%$ menyatakan efektif dan $20 \%$ menyatakan tidak efektif. Ternyata bimbingan dan konseling daring dinyatakan oleh $20 \%$ responden kurang efektif, pernyataan ini tentunya terkait dengan efektifitas layanan perbantuan yang diberikan guru BK dalam mencegah dan menyelesaikan masalah peserta didik seperti masalah belajar, 
pribadi, sosial maupun karir. Peserta menyatakan layanan BK daring masih kurang dalam hal proses interaksi yang intensif dan komunikasi yang efektif antara guru BK dengan peserta didik. Perubahan layanan BK daring dari tatap muka menjadi layanan daring menemui hambatan dan kesulitan sehingga kurang efektif diakibatkan interaksi dan komunikasi layanan yang kurang sebagaimana sebelumnya.

Keenam, unsur pemahaman peserta didik terhadap materi layanan BK yang berbasis daring, adalah sebanyak $94 \%$ memahami dan $6 \%$ tidak memahami. Pemahaman peserta didik terhadap materi layanan bimbingan dan konseling daring dipengaruhi oleh kemampuan/penguasaan anak-anak yang lebih melek (literasi) terhadap teknologi daring. Ternyata kemampuan peserta didik dalam pemanfaatan teknologi daring untuk menemukan informasi sebagai input memahami, menganalisis materi sangat baik. Beberapa peserta didik menyebutkan mereka nyaman dengan media daring seperti google classroom, zoom meeting, whatsapp, elearning yang digunakan guru BK dalam menyampaikan materi. Mereka menyatakan memperoleh pemahaman dan pencerahan baru, dapat mengerjakan tugas dengan gampang menggunakan sistem daring. Dengan demikian, layanan BK berbasis daring di madrasah menghasilkan pemahaman tentang materi layanan BK.

Ketujuh, unsur progres perbaikan peserta didik setelah selesai mendapatkan layanan BK daring, adalah sebanyak $89 \%$ ada progres dan $11 \%$ tidak ada progres. Layanan BK merupakan layanan perbantuan untuk mengembangkan pemahaman, sikap diri dan perilaku peserta didik. Pengembangan sikap dan perilaku membutuhkan teknik dan strategi komunikasi intensif dan membutuhkan waktu yang cukup. Dalam hal ini sebagian responden menyatakan tidak timbul sikap dan dorongan perbaikan setelah layanan BK daring ini, namun sebagian besar menyatakan ada progres sikap dari layanan yang diberikan. Peserta menyatakan melalui layanan daring kurang ada komunikasi efektif dan interaksi intensif serta contoh konkrit dari guru. Dengan demikian layanan BK daring membutuhkan strategi komunikasi yang efektif melalui interaksi intensif dan contoh konkrit.

Kedelapan, unsur kemandirian peserta dalam layanan BK daring, adalah sebanyak $72 \%$ menyatakan mandiri dan 28\% tidak mandiri. Kemandirian merupakan tujuan dari layanan BK, baik sikap dan perilaku mandiri, dalam proses layanan BK daring, kemandirian peserta berupa mandiri dan bertanggungjawab dalam mengatasi masalah pembelajarannya. Sebanyak $28 \%$ responden menunjukkan bahwa kemandirian peserta masih belum ada. Dengan demikian, kemandirian peserta didik perlu secara berkesinambungan ditingkatkan menggunakan strategi layanan yang lain.

Komponen-komponen implemen-tasi layanan BK daring setidaknya mencakup aspek proses dan hasil layanan BK. Aspek proses yang meliputi perasaan senang pada layanan BK daring, keaktifan berpartisipasi dalam layanan BK daring, berkonsentrasi dalam mengikuti layanan BK daring dan kemudahan menemukan sumber-sumber layanan BK daring adalah sebagai berikut:

\begin{tabular}{ccccc}
\hline & Senang & Keaktifan & Konsentrasi & Kemudahan \\
\hline$\%$ Ya & 83 & 92 & 74 & 94 \\
\%Tidak & 17 & 8 & 26 & 6 \\
\hline
\end{tabular}

Tabel 4. Proses Lananan BK Online

Tabel 4 menunjukkan bahwa proses layanan BK daring dalam kategori tinggi dengan $86 \%$ peserta menyatakan ya, sedangkan $14 \%$ menyatakan tidak. Data tersebut menunjukkan bahwa yang terendah adalah konsentrasi peserta didik dalam mengikuti layanan BK daring, sedangkan yang tertinggi adalah kemudahan 
mendapatkan layanan dalam BK dengan daring.

\begin{tabular}{lcccc}
\hline & Efektifitas & Paham & Proges diri & Kemandirian \\
\hline \% Ya & 80 & 94 & 89 & 72 \\
\% Tidak & 20 & 6 & 11 & 28
\end{tabular}

Tabel 5. Efek Layanan BK Online

Tabel 5 menunjukkan bahwa hasil layanan BK daring adalah $83,8 \%$ peserta menyatakan berhasil, sedangkan $16,2 \%$ menyatakan tidak. Data tersebut menunjukkan skor hasil layanan BK daring lebih rendah dibandingkan dengan skor proses. Berdasar data tersebut yang terendah adalah kemandirian peserta didik sedangkan yang tertinggi adalah pemahaman peserta terhadap materi layanan BK daring.

\section{Pembahasan}

Penelitian ini menemukan bahwa rerata seluruh komponen pelaksanaan layanan BK daring adalah $85 \%$ menyatakan ya, yang terdiri dari perasaan senang pada layanan $\mathrm{BK}$, keaktifan berpartisipasi dalam layanan BK, konsentrasi dalam mengikuti layanan BK, kemudahan menemukan sumber-sumber layanan BK, efektifitas layanan BK, pemahaman terhadap materi layanan BK, progres perbaikan setelah layanan BK dan kemandirian mengatasi masalah setelah layanan BK. Dengan demikian disimpulkan bahwa layanan BK daring di MTs telah terlaksana dengan baik, komponenkomponen pelaksanaan juga menunjukan rerata nilai baik terutama komponen proses layanan BK daring. Dari data pelaksanaan layanan bimbingan dan konseling daring yang masih kurang adalah bagaimana meningkatkan konsentrasi peserta dalam layanan daring agar fokus saat mengikuti layanan BK. Data efek layanan juga terdapat komponen kemandirian yang perlu ditingkatkan dengan rerata sebanyak 15\% yang menunjukkan hambatan, kesulitan atau masalah dalam layanan BK daring dan perlu solusi untuk peningkatan layanan BK.
Masa transisi perubahan layanan BK dari pola 'face-to-face', interaksi dan komunikasi langsung dengan ceramah, mendengar dan membaca berubah menuju layanan berbasis digital berbasis daring membutuhkan tahapan dan waktu yang cukup. Perlu dilakukan penyiapan peserta didik, sosialisasi layanan BK daring terhadap peserta didik terutama yang berasal dari lingkungan yang kurang familier dalam layanan daring, kelompok yang tidak memiliki fasilitas digital dan prasarana kuota internet.

Beberapa penelitian telah dilakukan terkait layanan pendidikan berbasis daring baik terhadap proses maupun hasil pembelajaran berbasis daring. Proses layanan sebelumnya berbasis tatap muka dan saat pandemi berubah berbasis daring, ini merupakan hal yang baru, sehingga guru maupun peserta didik mengalami situasi, cara baru bahkan dengan tantangan/kesulitan baru. Pendidikan berbasis daring, sudah banyak dilakukan, (Rachmat \& Krisnadi, 2020) memetakan bahwa $97,7 \%$ layanan daring menggunakan gawai yang memerlukan kuota. Penggunaan kuota ini menjadi kendala bagi layanan, karena $50 \%$ peserta didik mengalami kendala kuota, 45,5\% terkendala jaringan yang lambat, sedangkan 4,5\% terkendala tidak adanya media untuk pembelajaran daring. Sebagaimana (Rahman et al., 2020), dalam pembelajaran daring banyak peserta yang kebingungan karena sebelumnya layanan disampaikan dalam tatap muka. Kesulitan peserta didik dalam layanan daring karena peserta tidak memiliki gawai yang mendukung layanan, kesulitan jaringan/akses internet (Utomo et al., 2021).

Sebagaimana layanan pendidikan, layanan bimbingan dan konseling daring merupakan pola baru, yang tentu membutuhkan penyiapan sistem dan sosialisasi kepada semua pihak terkait agar senang pada layanan BK daring ini, bagaimana dapat aktif berpartisipasi dalam layanan BK daring, berkonsentrasi dalam mengikuti layanan BK 
daring dan mudah menemukan sumbersumber layanan. Namun ada yang bosan/ jenuh, kurang fokus dengan layanan daring, hal ini sesuai (Wahono \& Effrisanti, 2018) yang menyatakan karena kurang jelas tugas yang diberikan guru jika hanya diberikan lewat whatsapp atau e-learning.

Dalam proses layanan BK daring ternyata kemudahan layanan BK daring skornya tinggi, hal ini dapat dipengaruhi oleh kemampuan peserta memanfaatkan perangkat teknologi informasi dan komunikasi, kemampuan literasi digital untuk menemukan informasi, menggunakan informasi sebagai input pemikiran, untuk memahami, untuk menganalisis, memberikan penilaian terhadap berbagai informasi serta melakukan evaluasi terhadap informasi (Irhandayaningsih, 2020). Selain itu juga dibutuhkan kemandirian peserta didik dalam berpartisipasi aktif dalam layanan. Proses layanan bimbingan dan konseling daring yang dilaksanakan di madrasah masih ada peserta yang kebingungan dengan proses dan kurang maksimal hasil layanan yang diperoleh. Hal ini terjadi karena adanya hambatan dan kesulitan, sebagaimana (Akhmadi, 2020; Azzahra, 2020; Basar, 2021) yang menyatakan ada kendala dalam pembelajaran daring. Faktor latar belakang peserta yang kurang terbiasa dengan layanan daring, atau yang berasal dari daerah kepulauan dan pegunungan yang terhambat jaringan, atau penguasaan teknologi informasi komunikasi kurang. Dengan demikian layanan bimbingan dan konseling daring terdapat hambatan baik akses internet yang tidak merata dan keterampilan teknologi informasi dan komunikasi yang kurang.

Beberapa penelitian telah dilakukan terkait hasil layanan pendidikan berbasis daring. Hasil penelitian tentang efektifitas layanan BK yang mencakup pemahaman terhadap materi layanan BK, progres perbaikan setelah layanan BK dan kemandirian mengatasi masalah setelah layanan BK lebih rendah jika dibandingkan dengan prosesnya, hasil ini bersesuaian dengan (Abidin et al., 2020), yang menyatakan, di SMP dan SMA, 53\% responden menyatakan kurang memahami materi daring. (Rachmat \& Krisnadi, 2020) dalam penelitiannya menjelaskan bahwa $59,1 \%$ peserta didik kurang paham dengan pembelajaran daring, $56,8 \%$ menyatakan pembelajaran daring kurang efektif bagi peserta didik. Hambatan dalam e-learning adalah jaringan internet yang putus saat melakukan video conference, kuota internet yang terbatas untuk menuntaskan tugas, media yang kurang memadai untuk mengikuti layanan daring (Kahfi, 2020; (Krismadika, 2020). Karena hambatan itu, mereka menyatakan lebih mudah mengikuti layanan langsung, karena lebih jelas, detail, mudah untuk dipahami dan kalau ada materi yang kurang jelas dapat ditanyakan melalui tanya jawab dan diskusi. Hasil penelitian ini menjadi tanda bahwa terjadi perubahan cara layanan dari konvensional 'face-to face" menjadi daring dalam dunia maya berbasis digital, dari jarak dekat berubah jarak jauh yang perlu dipersiapkan.

Perubahan ini membutuhkan kesiapan peserta maupun perangkat layanan yang berbeda. (Astuti et al., 2019) menyajikan hasil penelitian bahwa metode tatap muka masih dianggap lebih baik dari pada e-learning karena lebih mudah memahami materi serta lebih mudah melakukan interaksi dengan pengajar. Dengan e-learning yang terorganisir, administrasi dan metode komunikasi yang memadai dengan multimedia komputer, televisi, telepon, radio, internet, video, WA, instagram dan sebagainya tentu menjadikan e-learning memiliki kelebihan dan fleksibilitas. Berbagai perubahan tersebut belum sepenuhnya disiapkan dan dikuasai peserta, sehingga perlu sosialisasi dan juga kesiapan sistem layanan maupun peserta didik (Septian et al., 2020). Hasil penelitian ini mendukung pendapat yang menyatakan perlunya 
perangkat layanan seperti tablet, laptop dan android yang memadai dalam layanan bimbingan dan konseling daring agar dapat dilaksanakan kapan dan dimana saja (Gozali, 2020).

Layanan BK daring merupakan model layanan jarak jauh yang memerlukan cara belajar mandiri (self study), yang diorganisir secara sistematis dalam penyajian materi, bimbingan, maupun pengawasan belajar. Efektifitas layanan BK daring terhadap pemahaman cukup tinggi karena siswa memiliki literasi digital. (Irhandayaningsih, 2020) menyebutkan bahwa literasi digital sebagai kemampuan memahami dan menggunakan informasi dalam berbagai format (teks, gambar, audio dan animasi) dan dari berbagai sumber yang tersaji melalui perangkat elektronik. Kemampuan ini juga termasuk pemanfaatan teknologi untuk menemukan informasi, menggunakan informasi tersebut sebagai input pemikiran, memahami, menganalisis, memberikan penilaian terhadap berbagai informasi serta melakukan evaluasi terhadap informasi tersebut.

Bimbingan dan Konseling merupakan layanan perbantuan yang diberikan guru BK untuk mencegah dan menyelesaikan masalah peserta didik baik masalah belajar, pribadi, sosial maupun karir dengan pendekatan psikologis dan edukatif (Nelissa et al., 2020). Tujuan utama layanan BK adalah kemandirian peserta didik, yang merupakan harapan dari setiap proses layanan BK. (Firdaus et al., 2021) menyatakan setiap layanan BK ditujukan untuk mewujudkan sikap dan perilaku mandiri. Kemandirian merupakan karakter yang sangat penting ditanamkan di dalam diri peserta didik (A. Y. Purwaningsih \& Herwin, 2020). Belajar mandiri dapat ditanamkan dengan sedikit atau sama sekali tanpa bantuan pihak luar, bahkan peserta didik dapat bertanggung-jawab atas keputusannya. Ternyata layanan daring ini belum optimal meningkatkan kemandirian peserta didik. Melalui belajar mandiri peserta didik dapat menggali potensi dalam dirinya sendiri karena belajar mandiri akan membangun pengetahuan yang sudah diketahui dan membentuk pengetahuan baru secara bertanggung jawab.

Menyikapi hasil penelitian ini, layanan bimbingan dan konseling daring perlu meningkatkan proses dan hasil yang lebih optimal. Layanan BK daring dilakukan dengan memberikan pengalaman layanan yang bermakna. Dalam bimbingan dan konseling (Sudirman, 2020) melakukan layanan ekonseling untuk membantu proses layanan yang tidak terbatas pada jam belajar saja, dengan fitur aplikasi yang familier dengan peserta didik. Model e-konseling yang dikembangkan (Jalil, 2021) terintegrasi antara guru BK dengan konseli, yang didasarkan atas kebutuhan inovasi yang dapat digunakan oleh guru BK dalam mengatasi permasalahan pribadi-sosial di sekolah sehingga efektif. Ekonseling yang dilakukan diharapkan efektif membekali peserta didik untuk perkembangan dirinya. Inovasi lain dalam layanan bimbingan dan konseling perlu dilakukan untuk meningkatkan layanan BK dimasa mendatang yang lebih efektif.

\section{PENUTUP}

\section{Simpulan}

Covid-19 telah menyebabkan terjadinya perubahan metode dan pendekatan layanan bimbingan dan konseling. Perubahan diakibatkan Covid-19 berdampak pada pengaturan menjaga jarak dalam kegiatan pendidikan, sehingga layanan pendidikan berbasis daring dengan sistem e-learning, ekonseling dengan bantuan teknologi informasi dan komunikasi.

Layanan BK daring dilaksanakan untuk pengembangan kompetensi kemandirian peserta didik dalam bidang belajar, pribadi, karir dan sosial merupakan pengalaman baru, berubah dari layanan tatap muka menjadi 
non tatap muka atau daring, berbasis teknologi informasi dan komunikasi. Perubahan tersebut membutuhkan piranti lunak dan perangkat keras, sehingga membutuhkan persiapan pada peserta maupun pelaksana.

Hasil penelitian ini menunjukkan bahwa layanan bimbingan dan konseling daring yang terdiri asesmen kebutuhan, layanan konseling, layanan bimbingan kelompok maupun klasikal serta evaluasi layanan berbasis daring terlaksana dengan skor baik. Proses layanan daring menyenangkan, memiliki kemudahan, dapat mengaktifkan peran peserta dalam kegiatan layanan. Efektifitas layanan BK daring termasuk kategori baik untuk aspek pemahaman materi layanan. Masih terdapat hambatan pada sarana prasarana layanan daring. Proses dan hasil layanan BK daring perlu dioptimalkan agar efisien dan efektif. Hambatan dan kesulitan layanan BK daring pada sarana prasarana daring perlu dipersiapkan untuk meningkatkan layanan BK.

\section{Rekomendasi}

Layanan BK daring menjadi cara baru berdasarkan kreasi dan inovasi guru BK dalam melayani peserta didik pada situasi pandemi Covid-19. Layanan BK daring perlu ditingkatkan proses dan hasilnya dengan melibatkan peserta didik, orang tua, guru BK dan madrasah. Pertama, peserta didik mendapat sosialisasi tentang sistem dan perlengkapan TIK yang perlu disiapkan/ dikuasai dalam layanan BK daring. Kedua, orang tua memberikan bekal motivasi dan perangkat digital kepada peserta termasuk lingkungan belajar yang diperlukan peserta didik. Ketiga, guru BK dan madrasah menyiapkan sistem layanan BK yang sederhana dan dilengkapi dengan blended learning. Keempat, pemerintah perlu menambah fasilitas kuota internet yang meringatkan beban peserta didik. 


\section{DAFTAR PUSTAKA}

Abidin, Z., Hudaya, A., \& Anjani, D. (2020). Efektifitas pembelajaran jarak jauh pada masa pandemi COVID-19. Research and Development Journal of Education. https://doi.org/10.30998/rdje.v1i1.7659

Akhmadi, A. (2020). Distance training evaluation in pandemi. Inovasi, 14 no 2, 136-144. https://scholar.google.co.id/citations

Almarzooq, Z. I., Lopes, M., \& Kochar, A. (2020). Virtual Learning During the COVID-19 Pandemic. Journal of the American College of Cardiology. https://doi.org/10.1016/j.jacc.2020.04.015

Arifiati, N., Nurkhayati, E., Nurdiawati, E., Pamungkas, G., Adha, S., Purwanto, A., Julyanto, O., \& Azizi, E. (2020). University Students Online Learning System During Covid-19 Pandemic: Advantages, Constraints and Solutions. In Systematic Reviews in Pharmacy.

Astuti, C. C., Sari, H. M. K., \& Azizah, N. L. (2019). Perbandingan Efektifitas Proses Pembelajaran Menggunakan Metode E-Learning dan Konvensional. Proceedings of the ICECRS. https://doi.org/10.21070/picecrs.v2i1.2395

Azzahra, N. F. (2020). Mengkaji Hambatan Pembelajaran Jarak Jauh di Indonesia di Masa Pandemi Covid-19. Center for Indonesians Policy Studies.

Basar, A. M. (2021). Problematika Pembelajaran Jarak Jauh Pada Masa Pandemi Covid-19. Edunesia : Jurnal Ilmiah Pendidikan. https://doi.org/10.51276/edu.v2i1.112

Faize, F. A., \& Nawaz, M. (2020). Evaluation and Improvement of students' satisfaction in Online learning during COVID-19. Open Praxis. https://doi.org/10.5944/openpraxis.12.4.1153

Fatoni, Arifiati, N., Nurkhayati, E., Nurdiawati, E., Fidziah, Pamungkas, G., Adha, S., Irawan, Purwanto, A., Julyanto, O., \& Azizi, E. (2020). University students online learning system during Covid-19 pandemic: Advantages, constraints and solutions. Systematic Reviews in Pharmacy. https://doi.org/10.31838/srp.2020.7.81

Fauzi, Z., Heiriyah, A., \& Matarif, J. (2020). Upaya Pelayanan Guru Bimbingan Dan Konseling Selama Pandemi Covid-19 Pada Siswa Di SMP Negeri 23 Banjarmasin. Jurnal Mahasiswa BK An-Nur.

Febriani, A., \& M Fauzi, A. (2021). Efektivitas Kebijakan Daring Bagi Pendidikan Konseling Dalam Meningkatkan Mutu Peserta Didik Di SMAN 1 Mejayan. Suluh: Jurnal Bimbingan dan Konseling. https://doi.org/10.33084/suluh.v6i2.2461

Fini, E., Lathuilière, S., Sangineto, E., Nabi, M., \& Ricci, E. (2020). Online Continual Learning Under Extreme Memory Constraints. Lecture Notes in Computer Science (including subseries Lecture Notes in Artificial Intelligence and Lecture Notes in Bioinformatics). https://doi.org/10.1007/978-3-030-58604-1_43

Firdaus, F. M., Pratiwi, N. A., Riyani, S., \& Utomo, J. (2021). Meningkatkan Kemandirian Belajar Peserta Didik Sekolah Dasar Menggunakan Model SOLE Saat Pandemi Covid-19. Foundasia.

Firman, F., \& Rahayu, S. (2020). Pembelajaran Online di Tengah Pandemi Covid-19. Indonesian Journal of Educational Science (IJES). https://doi.org/10.31605/ijes.v2i2.659

Gozali, A. (2020). Bimbingan dan konseling berbasis teknologi informasi pada masa PSBB ( Pembatasan Sosial Berskala Besar ). Jurnal Bimbingan Konseling Pendidikan Islam Coution : Journal of Counseling and Education Layanan. 
Irhandayaningsih, A. (2020). Pengukuran literasi digital pada peserta pembelajaran daring di masa pandemi covid-19. Anuva.

Jalil, M. N. (2021). Pengembangan Aplikasi E-Counseling Sebagai Upaya Meningkatkan Pemberian Layanan Bimbingan dan Konseling. Indonesian Journal of School Counseling: Theory, Application, and Development. https://doi.org/10.26858/ijosc.v1i1.19317

Jamaluddin, D., Ratnasih, T., Gunawan, H., \& Paujiah, E. (2020). Pembelajaran Daring Masa Pandemik Covid-19 Pada Calon Guru: Hambatan, Solusi dan Proyeksi. Karya Tulis Ilmiah UIN Sunan Gunung Djjati Bandung.

Kahfi, A. (2020). Tantangan Dan Harapan Pembelajaran Jarak Jauh Di Masa Pandemi Covid 19. Dirasah.

Kamalia, W., Suyati, T., \& Maulia, D. (2020). Layanan Bimbingan Klasikal Berbasis Daring Selama Masa Pandemik Covid 19. Dharmas Education Journal.

Kimkong Heng, \& Koemhong Sol. (2020). Online learning during COVID-19: Key challenges and suggestions to enhance effectiveness. Cambodian Education Forum (CEF).

Krismadika, A. P. (2020). Implementasi Pembelajaran Jarak Jauh Selama Pandemi Covid-19 Di Sd It Al-Huda Wonogiri. Jurnal Pandemi Covid-19.

Monteleoni, C. E. (2006). Learning with Online Constraints : Shifting Concepts and Active Learning Learning with Online Constraints. American Journal of Epidemiology.

Mukhtar, K., Javed, K., Arooj, M., \& Sethi, A. (2020). Advantages, limitations and recommendations for online learning during covid-19 pandemic era. Pakistan Journal of Medical Sciences. https://doi.org/10.12669/pjms.36.COVID19-S4.2785

Nelissa, Z., Hikmah, H., \& Martunis, M. (2020). Penerapan panduan operasional penyelenggaraan bimbingan dan konseling pada layanan bimbingan dan konseling. JRTI (Jurnal Riset Tindakan ....

Purwaningsih, A. Y., \& Herwin, H. (2020). Pengaruh regulasi diri dan kedisiplinan terhadap kemandirian belajar siswa di sekolah dasar. Jurnal Penelitian Ilmu Pendidikan. https://doi.org/10.21831/jpipfip.v13i1.29662

Purwaningsih, H. (2021). Peran guru bimbingan dan konseling dalam melayani peserta didik di masa pandemi COVID-19. EDUCATIONAL : Jurnal Inovasi Pendidikan \& Pengajaran. https://doi.org/10.51878/educational.v1i1.53

Putra, M. A., \& Shofaria, N. (2020). Inovasi layanan bimbingan dan konseling di masa pembelajaran dalam jaringan pandemi COVID-19. Bikotetik (Bimbingan dan Konseling Teori dan Praktik). https://doi.org/10.26740/bikotetik.v4n2.p55-61

Rachmat, A., \& Krisnadi, I. (2020). Analisis Efektifitas Pembelajaran Daring (Online) Untuk Siswa SMK Negeri 8 Kota Tangerang Pada Saat Pandemi Covid 19. Jurnal Pendidikan.

Rahman, M. A., Amarullah, R., \& Hidayah, K. (2020). Evaluasi Penerapan Model Pembelajaran E-Learning pada Pelatihan Dasar Calon Pegawai Negeri Sipil. Jurnal Borneo Administrator. https://doi.org/10.24258/jba.v16i1.656

Rimawati, E., \& Saptomo, W. L. Y. (2019). Analisis Diskriptif Technologi Acceptance Model pada Penerapan Blended Learning. Jurnal Ilmiah SINUS. https://doi.org/10.30646/sinus.v17i2.420

Rokhyani, E. (2021). Inovasi Layanan Bimbingan Dan Konseling Pada Masa Dan Pasca Pandemi Covid-19. PD 
ABKIN JATIM Open Journal System.

Sadikin, A., \& Hamidah, A. (2020). Pembelajaran Daring di Tengah Wabah Covid-19. BIODIK. https://doi.org/10.22437/bio.v6i2.9759

Satuan Tugas Penanganan COVID-19. (2021). Analisis Data Covid-19 Indonesia Update Per 16 Mei 2021. Satuan Tugas Penanganan COVID-19.

Septian, F., Syaripudin, A., \& Punkastyo, D. A. (2020). Pelatihan Pendidikan Jarak Jauh Berbantuan Media Sosial Edmodo Bagi Guru Smp Terbuka Sawangan Depok. JAMAIKA: Jurnal Abdi Masyarakat.

Sudirman. (2020). Optimalisasi Peran Konselor Sekolah Dengan Implementasi Aplikasi Layanan Bimbingan \& Konseling ( e - Konseling ) Pada Sekolah Menengah Atas. Jurnal Mahajana Informasi.

Utomo, K. D., Soegeng, A. Y., \& ... (2021). Pemecahan Masalah Kesulitan Belajar Siswa pada Masa Pandemi Covid-19. MIMBAR PGSD ....

Wahono, H. T. T., \& Effrisanti, Y. (2018). Literasi Digital di Era Millenial. Prosiding Seminar Nasional Hasil Penelitian Pendidikan dan Pembelajaran STKIP PGRI Jombang.

Wahyu, A., \& Simanullang, R. H. (2020). Student stress due to online learning during the COVID-19 pandemic. Jurnal Aisyah: Jurnal Ilmu Kesehatan. 